\title{
ACKNOWLEDGMENTS
}

\section{Gonzalo Fernández de Oviedo took}

decades to complete his lengthy history of the New World. My study of his five-volume text has spanned nearly two decades as well. While at Brown University, I took a course with Alan S. Trueblood on Renaissance dialogue, and Stephanie Merrim suggested I study Fernández de Oviedo's dialogue about Hernán Cortés. That seminar paper became the first of several articles I published on Oviedo in the early I990s. These two professors, along with José Amor y Vázquez, Roberto González Echevarría, and Geoffrey Ribbans, continually encouraged me as I headed into new territory. During these years, I also had the good fortune to discover a section of Oviedo's autograph manuscript, the most extensively illustrated volumes, at the Huntington Library in San Marino, California. This serendipitous event led to years of tracking down all extant sections of the manuscript, a search that included trips to nine libraries in the United States and Spain.

I owe a tremendous debt of gratitude to the numerous people and institutions who helped me with research, funding, and early drafts of articles. Rolena Adorno guided my research at a National Endowment for the Humanities Summer Institute held at the Newberry Library. William Frank, Amy Meyers, Jane Munro, and Carla Pestana worked with me during my fellowships at the Huntington Library. Linda Curcio-Nagy, Charles Ganelin, Amanda Powell, Enrique Pulpo-Walker, and Jerry Williams read and commented on drafts of several articles, as did my colleagues at Indiana University, Gordon Brotherston, Catherine Larson, James Mandrell, and Frances Wyers. Chapters 4 to 6 of this book are revised versions of these three articles from the early I990s. My thanks to the editors at Hispania and the University of Arizona Press for the rights to republish them. 
After a five-year hiatus from working on Oviedo's General and Natural History of the Indies while I completed several other projects, I was awarded a research grant from Spain's Ministry for Education and Science to work with Dr. Fermín del Pino at the Consejo Superior de Investigaciones Científicas in Madrid. There I continued the task of weaving together a book that would take into account three aspects of Oviedo's work that deeply influenced the writing of his text: the complex story of Oviedo's drafts of the History, Oviedo's personal and political ambitions, and period rhetorical structures and genres. I found that most of the existing studies about his History tended to focus on only one or two of these aspects, or focused on either the general or natural history, leaving aside how the two work together. Fermín served as an enthusiastic and knowledgeable interlocutor, and our discussions were often enriched by Jesús Carrillo and Luis Millones, two scholars who were completing their dissertations at the time. The staffs at the Madrid libraries that hold portions of Oviedo's manuscript, the Biblioteca Nacional, Real Academia de Historia, and Palacio Real, all in Madrid, also offered enormous help. Arantxa Domingo was particularly helpful.

The final stage of my archival work and drafts of book chapters took place in the past few years, when Indiana University, the American Philosophical Society, and the Ministry for Cultural Cooperation Between Spain and the United States all provided generous financial support for travel to Spain in order to attain photographs of the manuscript and to carry out research at the Archive of the Indies, which houses nearly two hundred documents that deal with Oviedo's life and works. My stay in Seville was greatly enhanced by the collegial reception Berta Ares Queija and Salvador Bernabeu offered me at the Escuela de Estudios Hispanoamericanos and by the staff at the Biblioteca Colombina. My thanks also go to the staff at the Hispanic Society of New York, which houses a rare nineteenth-century copy of Oviedo's History.

Upon completion of my book, Álvaro Félix Bolaños, Mark Feddersen, William L. Myers, and Nina M. Scott provided valuable comments on the whole manuscript. Licia Weber skillfully and enthusiastically collated and formatted the illustrations. My graduate students at Indiana University, Hernán Feldman, Eric Harzman, and Amber Ray García, helped prepare the manuscript for publication. In particular, Pablo García worked tirelessly as a research assistant, reader, and computer guru. With grace and expertise Lynne Chapman, my editor at the University of Texas Press, guided the manuscript into its final form.

As always, friends and family played an important role in keeping me 
going during all these years. A big thanks goes to my good friends Rob and Karen Green Stone, who provided a quiet haven many summers for me to write, and to my husband, Mark Feddersen, who, besides being the best editor around, served as a constant source of encouragement.

Finally, I owe my deepest gratitude to my parents, Mary Tyrrell Myers and Richard James Myers. My dad was the first historian I knew and is still the best. My mom has been my biggest fan, even reading all my footnotes. They have inspired me in countless ways during my life. 
THIS PAGE INTENTIONALLY LEFT BLANK 
FERNÁNDEZ DE OVIEDO'S CHRONICLE OF AMERICA 
THIS PAGE INTENTIONALLY LEFT BLANK 